\title{
The Social-Environmental Justice of Groundwater Governance
}

\author{
Marian J. Neal (Patrick), Francesca Greco, Daniel Connell, \\ and Julian Conrad
}

\begin{abstract}
Groundwater is but one component of the hydrological cycle. It interacts with and is dependent on how the other components of the hydrological cycle are managed. The rationale for sharing or allocating groundwater is guided by the principle of equitable and reasonable utilization. There is no universal theory of justice to which we can appeal, to help us operationalise this principle to the satisfaction of all water uses and users. Often the losers in allocation decisions are marginal communities or disempowered individuals or groups, and the natural environment. This results in the emergence of a variety of social and environmental injustices, especially if the burden falls continuously on the same group or ecosystem. Social - Environmental justice is a useful lens in the arsenal of researchers, policy makers and natural resource managers that can be used to highlight the importance of a systems approach when dealing with common pool resources such as groundwater.
\end{abstract}

M.J. Neal (Patrick) ( $₫)$

SIWI, Stockholm, Sweden

e-mail: marian.patrick@siwi.org

F. Greco

United Nations-World Water Assessment Programme-UN-WWAP, UNESCO, Perugia, Italy e-mail: francescagreco78@gmail.com

D. Connell

Crawford School, Australian National University, Canberra, ACT, Australia

e-mail: daniel.connell@anu.edu.au

J. Conrad

GEOSS - Geohydrological \& Spatial Solutions International (Pty) Ltd., Stellenbosch, South Africa

e-mail: jconrad@geoss.co.za; http://www.geoss.co.za 


\subsection{Why Justice Matters in Water Governance}

Water allocation is a fundamental part of water governance. It has been described as an unavoidable conflictual process because it is fundamentally a political process and it involves multiple, competing uses and users of water (Allan 2005). The scarcity of water resources, driven by anthropogenic or natural means, exacerbates an already politically sensitive process. Issues of justice arise when resources are, or are perceived to be, in short supply or when access to water resources is restricted or refused (Wenz 1988). In these situations individuals or groups are concerned about getting their fair share and arrangements are made, or institutions created, to manage, allocate and regulate the water resources in question.

This concern about getting one's fair share arises when an individual or group feel that others are either not contributing their fair share to a public good or are taking more than their fair share from a common or communal resource (Schroeder et al. 2003). In water governance this concern revolves primarily around the latter, and can (and has) resulted in winners and losers in water allocation and access. This uneven spread of benefits and burdens presents a problem because the burden of being the loser in a water sharing or allocation arrangement can impact negatively on one's livelihoods or can be detrimental to ecosystem health; and often results in some degree of discontent or even conflict. Often the losers are marginal communities or disempowered individuals or groups, and the natural environment. This results in the emergence of a variety of social and environmental injustices, especially if the burden falls continuously on the same group or ecosystem.

Groundwater resources are increasingly threatened (Chap. 2), with the recent data from the GRACE satellites depicting the rapid rate of decline in almost all the major aquifers in the arid and semi-arid parts of the world (Goldenberg 2014). The continued unsustainable extraction of groundwater is laying the foundation for more discontent and potential conflict over this resource. A recent study of international transboundary aquifers shows that $8 \%$ of transboundary aquifers worldwide are currently stressed due to human overexploitation (Wada and Heinrich 2013).

\subsection{Challenges of Groundwater Governance}

A focus on groundwater management and allocation is important yet it must not cloud the reality that groundwater is but one component of the hydrological cycle and that it interacts and is dependent on how the other components of the hydrological cycle are managed. It also cannot be regarded from a solely hydrological perspective (Chap. 3) - it is linked to other physical systems (soils, ecosystems, oceans, and atmosphere) and importantly to related social, cultural, economic, legal, institutional and political systems (UNESCO 2012).

Successful groundwater governance is challenging because of its interdependence with these other systems. These challenges are exacerbated because groundwater is a resource hidden from view and therefore the impacts of its use are difficult to monitor and evaluate. The importance of groundwater to society is 
overshadowed by the more visible surface water in rivers, lakes and reservoirs, yet the majority of the world's drinking water comes from groundwater and it supports an ever increasing agricultural sector (Giordano 2009). Groundwater allocation and sharing arrangements are further complicated by scientific uncertainties (Chap. 28) - the limited capacity to quantify surface water - groundwater interactions; aquifer recharge rates; and groundwater-dependent-ecosystem responses to fluxes in groundwater quantity and quality.

The rationale for sharing or allocating groundwater can draw on a variety of principles or values that we as human beings have constructed and developed over time to underpin our decision-making processes. In water management the call for equitable and reasonable utilization of water resources is a common guiding principle but it demands reflection on what we mean by equity and how this translates into practice. We need to be able to articulate what principles or values we draw upon to ensure that the outcome of water sharing is considered equitable or just. And herein lies an additional challenge - there is no one correct answer; there is no universal theory of justice to which we can appeal, to help us answer this question to the satisfaction of all water uses and users.

\subsection{Defining Justice}

Justice is a concept that most people commonly associate with the legal system justice will be served when a wrong is righted. In the ambit of ethics something is just if it adheres to the current sanctioned value discourse - the problem being of course is that there is always some disagreement on what that discourse is (Colquitt et al. 2001). The meaning of justice in the context of its role in decision-making and resource allocation is multifaceted and is described in many different disciplines. For the purposes of this chapter, a brief examination of the trends of justice research in the social psychology literature helps define the concept.

In the 1960s and 1970s much of the justice literature assumed that people's sense of justice was concerned with the distribution of outcomes or resources based purely on motivations of self-interest (Skitka and Crosby 2003). Equity theory provided the prominent distribution or outcome orientated viewpoint. Equity is achieved according to Adams (1963) when a person's rewards or outputs are perceived to be in proportion to that person's inputs or contributions. In other words equity is affected by what is termed the contributions rule (Leventhal 1976), where a person who contributes greater should receive higher rewards or outputs. ${ }^{1}$ There were some challenges to this mainstay theory. Deutsch (1975) introduced two additional rules that determine how rewards or outputs could be

\footnotetext{
${ }^{1}$ It is assumed that the use of terms 'equity' and 'equitable' in many water laws, regulations and strategies do not intend to use it in this narrow sense but rather in a broad justice sense- this however does contribute to some of the confusion over the use of term and its implications for water allocation.
} 
distributed, these are the needs rule, where a person who has a greater need should receive higher rewards or outputs; and the equality rule, where everyone should receive equal rewards or outputs regardless of their needs or contributions. Equity (or contributions), needs and equality are rules that are used to determine how resources or rewards could be distributed. They are often referred to in the literature as the distributive justice rules.

These 'rules' however all focus on the distribution of outcomes or allocation of resources. During the late 1970s and 1980s research shifted from distribution to procedural issues. Thibaut and Walker (1975) (and Deutsch and Leventhal) expanded the notion of justice to include not only distribution rules but also procedural rules. They contend that the manner or procedures in which the allocation of rewards or outputs are decided is also critical for determining what is just. The main premise of procedural justice is that the output or final distribution of resources is more likely to be accepted as just or fair ${ }^{2}$ if the manner in which the decision was made is deemed to be just or fair by the affected parties. In the 1980s and 1990s, since Thibaut and Walker's initial ideas on procedural justice, many more facets of procedural justice have been posited as important to defining procedural justice. They include inter alia the need for consistency, accurate information, opportunity to correct decisions, representation of all affected parties, interpersonal behaviour, articulation of reasons for allocation decisions, accountability and treating affected parties with respect (Brockner and Wiesenfeld 1996; Gross 2011).

Distributive and procedural justice provide some insight into the complexity of defining and understanding justice especially in the context of water resources governance where both distributional and procedural rules apply. If however we delve a little deeper into the literature, the concept of justice becomes even more textured and layered. There are many models of justice which attempt to provide an underlying or unifying explanation of why we make the decisions we do, and how we should make decisions in specific contexts. This Holy Grail - that there exists a unifying theory of justice - has not yet materialised, and is unlikely to in the near future (Wenz 1988). The reality is that there are many competing principles or perspectives of justice that can be used to make convincing arguments for the advocacy of quite contrary positions.

There is an extensive history and array of research that has contributed to the development of the many theories of justice; and a wide ranging review would not be appropriate for the purpose of this chapter. The aim here rather is to present a brief overview that provides sufficient background on the range of existing justice theories but also focuses on some that are relevant to groundwater governance. Bearing this in mind, four families of theories are described in Table 10.1: they are an economic family, a rights-based family, a social family and an environmental family. The description of each theory is a summary adapted from Wenz (1988) who provides a more detailed overview of a number of models and theories of justice.

\footnotetext{
${ }^{2}$ The terms fair or fairness is often used in the social psychology literature rather than the terms just or justice - in this chapter they are considered synonymous and are used interchangeably.
} 
Table 10.1 A non-exhaustive summary of the various justice theories, principles and models (Adapted from Wenz 1988)

\begin{tabular}{|c|c|c|}
\hline \multirow[t]{4}{*}{$\begin{array}{l}\text { The economic } \\
\text { family }\end{array}$} & \multicolumn{2}{|c|}{$\begin{array}{l}\text { Efficiency is the driving force behind this family of justice theories where } \\
\text { maximising surplus is advocated. This family is represented by the following: }\end{array}$} \\
\hline & $\begin{array}{l}\text { Libertarian } \\
\text { theory }\end{array}$ & $\begin{array}{l}\text { Provides an underlying rationale for settling all issues of } \\
\text { justice through the free market (and the courts). People } \\
\text { have the right to be able to buy and sell whatever they want } \\
\text { so long as they don't use force or fraud }\end{array}$ \\
\hline & $\begin{array}{l}\text { Efficiency } \\
\text { theory }\end{array}$ & $\begin{array}{l}\text { Is similar to libertarian theory in that it advocates a free } \\
\text { market where there is a minimal State that protects private } \\
\text { property but does not interfere with the economy. It differs } \\
\text { in the means to achieving this goal in that it advocates } \\
\text { maximum efficiency rather than the right to liberty and } \\
\text { private property as its central tenet }\end{array}$ \\
\hline & $\begin{array}{l}\text { Cost-benefit } \\
\text { analysis }\end{array}$ & $\begin{array}{l}\text { Although a technique rather than a theory, cost-benefit } \\
\text { analysis is often used in decision making. It is underpinned } \\
\text { by the principles of Efficiency and Utilitarian (see below) } \\
\text { theory. CBA analyses alternative courses of action based } \\
\text { on the costs and benefits (primarily expressed in monetary } \\
\text { terms) associated with each, and recommends the option } \\
\text { with the greatest benefits and/or lowest costs as the most } \\
\text { desirable choice }\end{array}$ \\
\hline \multirow{3}{*}{$\begin{array}{l}\text { The rights- } \\
\text { based family }\end{array}$} & & \\
\hline & Human rights & $\begin{array}{l}\text { Provides a means of settling disputes by appealing to } \\
\text { fundamental human rights. These comprise negative rights } \\
\text { which are rights to non-interference (e.g. people's life, } \\
\text { liberty, expression, religion or property) and positive } \\
\text { rights which are rights to assistance (e.g. health, education } \\
\text { and wellbeing). In } 2010 \text { the UN General Assembly } \\
\text { amended the Declaration of Human Rights to include the } \\
\text { right to water and sanitation as a human right (UN 2010) }\end{array}$ \\
\hline & Animal rights & $\begin{array}{l}\text { Provides a means of settling disputes by appealing to } \\
\text { fundamental animal (or non-human animal or subjects-of- } \\
\text { a-life) rights. Animal rights comprise negative rights such } \\
\text { as right to life and freedom, and apply to wild animals. In } \\
\text { most countries positive animal rights only come into play } \\
\text { when dealing with domesticated animals }\end{array}$ \\
\hline \multirow[t]{3}{*}{$\begin{array}{l}\text { The social } \\
\text { family }\end{array}$} & \multicolumn{2}{|c|}{$\begin{array}{l}\text { These theories generally reflect a concern for the welfare of society. Two of } \\
\text { the most popular and well known theories are: }\end{array}$} \\
\hline & $\begin{array}{l}\text { Utilitarian } \\
\text { theory }\end{array}$ & $\begin{array}{l}\text { Provides a rationale for making decisions, taking action } \\
\text { and designing policies that produce the greatest good. This } \\
\text { theory supports decisions that maximise happiness or } \\
\text { preference satisfaction, and is laudable in its aim to } \\
\text { improve the wellbeing of all people }\end{array}$ \\
\hline & $\begin{array}{l}\text { Rawls' theory } \\
\text { of justice }\end{array}$ & $\begin{array}{l}\text { Rawls offers a hybrid theory that reconciles the } \\
\text { consideration of rights and utility. The basic premise of the } \\
\text { theory is that decisions can be made based on which } \\
\text { alternatives offer the most help for the worst off or that the } \\
\text { worst possible outcome is made as good as it can be. Thus } \\
\text { decisions are made on principles that are considered fair } \\
\text { for everyone without any prejudice }\end{array}$ \\
\hline
\end{tabular}


Table 10.1 (continued)

\begin{tabular}{l|l|l}
\hline $\begin{array}{l}\text { The } \\
\text { environmental } \\
\text { family }\end{array}$ & $\begin{array}{l}\text { These theories focus on ecosystem and environmental concerns, values } \\
\text { and/or rights; and shine a light on the need to take the environment into } \\
\text { account when making decisions about natural resource management and } \\
\text { allocations; they are important when sustainability issues are taken seriously }\end{array}$ \\
\hline $\begin{array}{l}\text { Biocentric } \\
\text { individualism }\end{array}$ & $\begin{array}{l}\text { Is not a justice theory per se, but is a perspective that } \\
\text { contributes to the discussion. It is based on the belief that } \\
\text { there is value in every living thing and that people have an } \\
\text { obligation to take this value into consideration whenever } \\
\text { their actions affect living things }\end{array}$ \\
\hline $\begin{array}{l}\text { Ecocentric } \\
\text { holism }\end{array}$ & $\begin{array}{l}\text { Is a view that people should limit their activities out of } \\
\text { concern for the continued existence of a species and the } \\
\text { continued health of ecosystems. It is also not a theory per } \\
\text { se, but offers an additional view point that considers the } \\
\text { broader environment in decision making }\end{array}$ \\
\cline { 2 - 3 } & $\begin{array}{l}\text { Often referred to when development has the potential to } \\
\text { impact negatively on the environment. Where there is a } \\
\text { risk of irreversible harm or damage, the absence of } \\
\text { principle } \\
\text { developencent cannot be used as a reason to proceed with }\end{array}$ \\
\hline
\end{tabular}

The array of rules, theories and principles that can be called upon in order to determine on what basis water resources can be shared and allocated between users is vast and not only are they used in the allocation context, they are also used in determining who should be included or count as a potential water user and who is not, before any discussion on water allocation and access is initiated.

\subsection{Why Justice Should Be Considered in Groundwater Governance}

Even though justice is a complex, nebulous concept, it is imperative to give it due consideration since the consequences of not doing so can undermine the best groundwater management intentions. By articulating the practical meaning of equitable distribution of resources, the concept of justice also serves to illustrate the importance of a systems thinking approach when developing groundwater management plans or when managing conflict over scarce water resources.

The following case studies highlight the importance of considering groundwater as part of an inter-dependent web of systems, and the necessity of including local communities and the environment in the decision-making and allocation process in order to avoid or ameliorate potential social and/or environmental injustices.

\section{Case Study 1: The Daly River, Northern Territory, Australia}

Hydrological systems of the Northern Territory in Australia are currently the subject of a national debate about whether they should be used to support the expansion of irrigated agriculture in that region. A central focus is the Daly River 
catchment just south of Darwin. During the dry season it is one of the few rivers with flow. The Daly system does not have potential sites for large dams, therefore any expansion of irrigation would need to be based on withdrawals from groundwater or directly from the river itself which is sustained during the long dry season by groundwater inflows originating upstream. These groundwater systems currently support a mosaic of many dependent ecosystems with high biological diversity. They would be severely impacted if irrigation development goes ahead as proposed (Blanch et al. 2005).

When irrigation is supplied by releases from dams or directly from surface runoff it is usually the case that the greater the volume of extractions the more intense will be the impacts on the environment. With groundwater dependent ecosystems in the Northern Territory this pattern is reversed (DNREA 2006). It often takes only a relatively small level of extraction for the groundwater table to no longer intersect with the low lying parts of the land surface where it previously created permanent and semi-permanent wetlands. This can transform a landscape with many wetlands into a dry dusty semi desert (Blanch 2004).

The Daly River catchment includes the town of Katherine, the fourth largest in the Northern Territory and Pine Creek both with substantial Indigenous populations as well as Nauiyu, a wholly Indigenous community (Fig. 10.1). There are at least

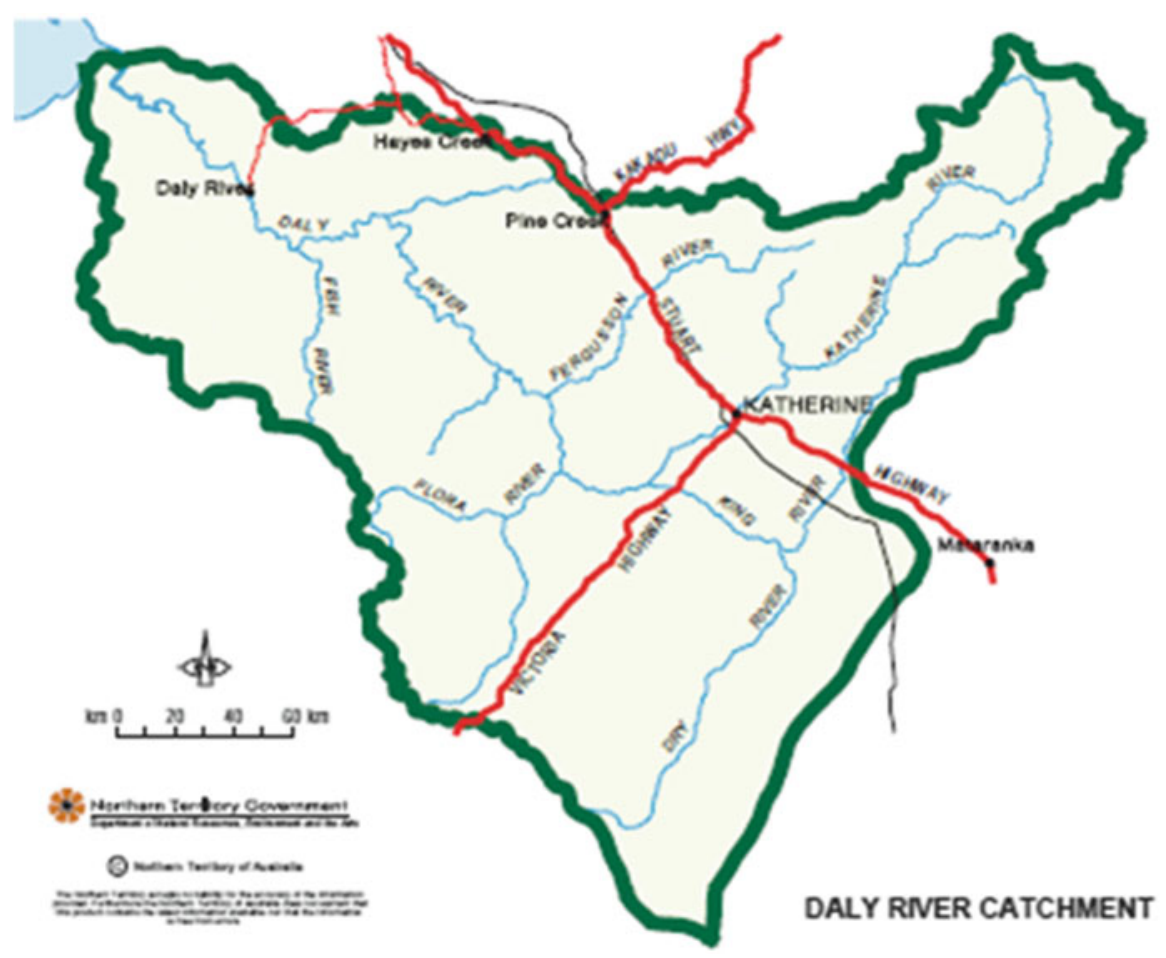

Fig. 10.1 Location of Daly River catchment, Northern Australia 
ten Indigenous language groups in the region. The current landscape with its many wetlands is of great cultural significance to the Indigenous peoples of the region. Indigenous people make up about $25 \%$ of the population of the Northern Territory and manage more than $30 \%$ of its area.

In addition to the threats from proposals for future development the clear waters of the Daly River are already under pressure from current agricultural and pastoral activities that are causing increased sedimentation. High levels of water clarity are needed to support the growth of aquatic plants such as Vallisneria nana - the key food source for pig-nosed turtles. A very significant species for the local Indigenous communities, this species of turtle is found in only a few rivers in Australia and Papua New Guinea. It is highly vulnerable because of its nutritional dependence on this single food source and its unusual breeding process. The favoured nest sites are fine sand riverine banks in the middle and lower reaches of the Daly River. Turtles rely on warm water discharged from springs to keep warm. During reproduction the females rarely move from these places. The sex of young turtles is determined by the temperature of the water within which they hatch. If water levels are reduced due to water extraction for irrigation, nests may dry out earlier and become hotter thereby reducing the percentage of males which only hatch in cooler nests (Blanch et al. 2005).

Indigenous interests in water are a complex mix of culture and economics, the latter term covering everything from traditional activities such as hunting, fishing and gathering wild plants to eco-tourism and to irrigated agriculture. The National Water Initiative (NWI) approved by the Council of Australian Governments in 2004, placed a very high priority on the need to take account of Indigenous interests in water planning and management. However, the NWI was frustratingly vague about how that should be done and some of its elements make it hard to achieve change. For example, the separation of entitlements to water from titles to land in order to promote water trading creates a serious challenge because it undermines the Indigenous conception that land and water are integrally connected. According to Jackson (2004), Indigenous interests do not translate easily into Western environmental management frameworks which are based on objectification and quantification. The concept of environmental flows, especially when costed in monetary terms, is an example of this tendency to define everything in quantifiable units so that they will be easy to compare and allocate.

Drawing on a large body of research, Jackson (2005) has described a relationship between water and Indigenous people which is more complex than that of European settlers in the region. She argues that in the latter case the cultural dimension is a diffuse and poorly articulated aesthetic and emotional response that tends to be secondary to the focus on economic goals defined in monetary terms. Indigenous connections are more complex and can only be reduced to monetary values with a significant loss of cultural meaning and richness. For example Western systems give priority to land as measured and allocated to particular owners as the basic unit for natural resource management. To a limited extent Indigenous interests in land can be taken into account with this approach but developing a similar approach for water has proved difficult. Jackson et al. (2005) have argued that this is one reason why there has been greater recognition of Indigenous relations with land rather than 
with water and the wider ecological system (Jackson 2006). Arguably this disproportionate emphasis on land rather than on the ecosystem as a whole has led to a serious underestimation of the importance of water to Indigenous people. This is despite the commitment contained in the National Water Initiative which states that water plans must take account of Indigenous issues by making arrangements for Indigenous representation in water planning 'wherever possible' and provision for indigenous social, spiritual and customary objectives 'wherever they can be developed'. They should also include allowance for 'the possible existence of native title rights to water in the catchment or aquifer area' (National Water Commission 2004, paras 52-54). Given the long delays in implementing these commitments it is likely that land and water policy in northern Australia will be highly contested in coming years.

The proposed extraction of groundwater within the Daly River region for increased agricultural production needs to weighed against the potential impacts on the groundwater dependent ecosystems, their supporting flora and fauna such as Vallisneria nana and pig-nosed turtles, and most especially the fragile links with sites and species of cultural significance to the local Indigenous communities. Disregard of the interdependencies of economic, social and environmental uses of water in Daly River catchment could result in social and environmental injustices with long term impacts.

\section{Case Study 2: The Disi Aquifer: Saudi Arabia and Jordan}

Jordan is one of the most arid countries on earth. The residents of Amman, the capital of Jordan, receive running water twice a week (prior to 2002 it was only once a week). The majority of the population lives in the Greater Amman area in the North, an urban conglomerate which is also a final destination for refugees from Iraq, Syria and, historically, from Palestine. The Disi Aquifer lies south of Amman, between the South of Jordan and the northern part of Saudi Arabia (Fig. 10.2). The majority of the aquifer is located in Saudi Arabia. By the 1990s, Saudi Arabia was extracting nine times as much water as Jordan and in 1992 Jordan accused the Saudis of overpumping, but the Saudi government did not respond in any way to the accusation (Shapland 1997).

The Disi Aquifer (called the Saq aquifer in Saudi Arabia) is a reservoir of fossil water, $3,000 \mathrm{~km}^{2}$ wide, with exploitable reserves estimated around 6,250 MCM (million cubic meters) (Foster and Loucks 2006), it has a minimal recharge such that it is considered 'non-renewable' in all major international classifications (USGS 2013). There is no bilateral treaty between Jordan and Saudi Arabia; despite that, a memorandum of understanding has long been due between the two countries, as they have so far not reached a formal agreement over the use of this shared water resource. During the 1980s and the 1990s, the Jordanian side of the overlying fields, around 10,000 ha, has been rented to agri-business companies in order to produce different export crops and, later on, also fruits and vegetables, consuming around $75 \mathrm{MCM} / \mathrm{year}$ and not paying any water fees (Ferragina and Greco 2008). When agri-business companies were granted the land in the 1980s, the concept of 'transboundary groundwater' barely existed. The agri-business companies exploiting the Disi aquifer on the Jordanian side were given incentives to exploit 


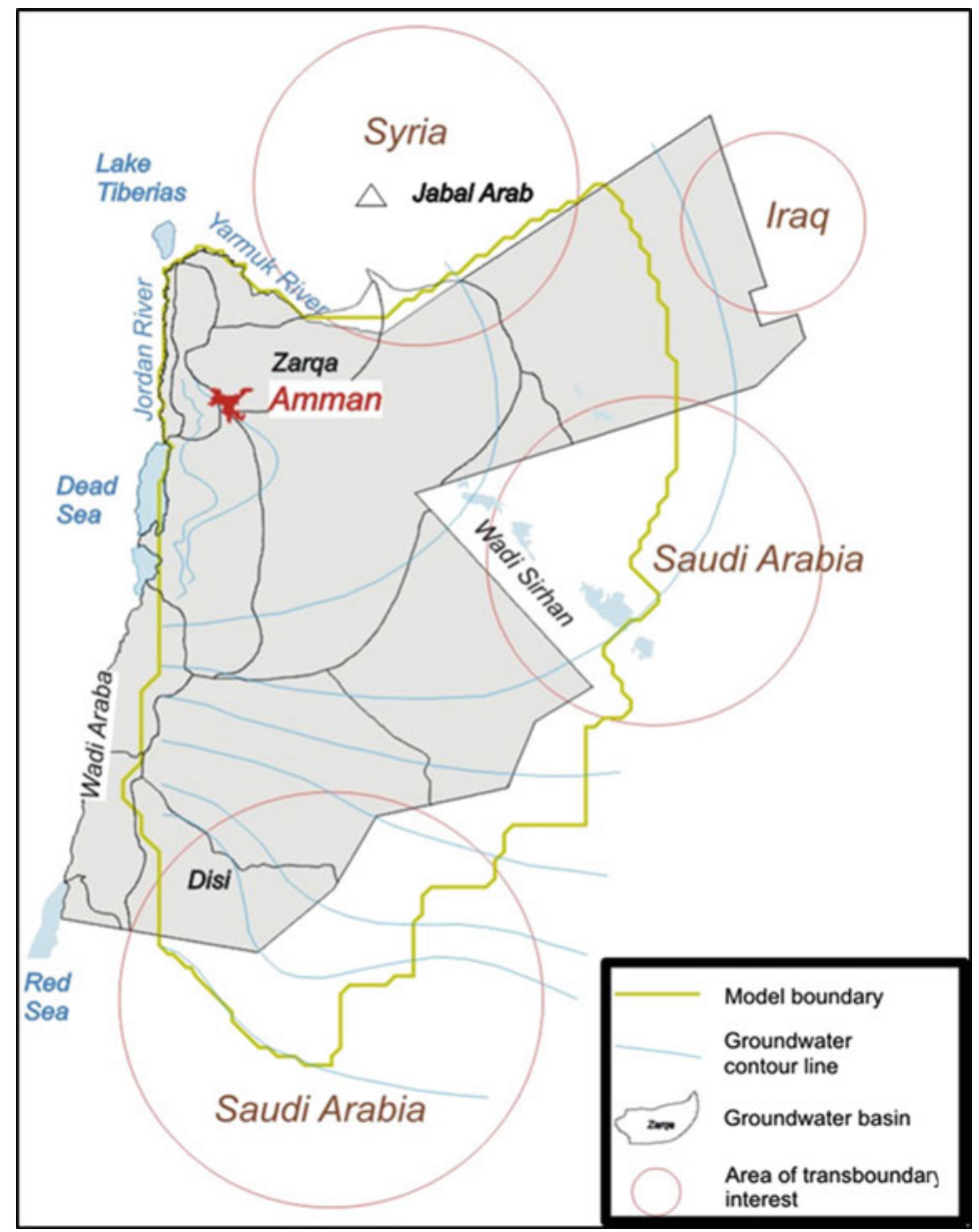

Fig. 10.2 Location of Disi Aquifer (Source: BGR 2013)

the resource in the $1980 \mathrm{~s}$, this encouragement ended in recent times due to a planned alternative use of the Disi water: to supply Amman via a $350 \mathrm{~km}$ long pipeline. When the planning for pipeline project was initiated, the agri-business companies were given a deadline; they were to cease farming before the end of 2012, in order to stop pumping the water from the aquifer, and in order to allow the diversion of all the resources to the capital city of Amman.

The World Bank did not agree to fund the pipeline project because of the lack of a bilateral treaty between Jordan and Saudi Arabia; which was judged by the bank as a preliminary condition for the good outcome of the project. Today, the pipeline is almost completed, funded by other international lenders such as Agence Française de Développement (AFD), the European Investment Bank (EIB), the Overseas Private Investment Corporation (OPIC), and the Promotion et Participation pour la Coopération économique (PROPARCO). The main problem with this 
project was that it was a top-down approach, where consultation with the local populations of the desert and the Bedouin groups remained very low. The construction of the pipeline has been contested, resulting in two workers being killed by the local Bedouins, who were asserting that the project company did not include them in the economic benefits of the work in general and, particularly by not renting their trucks for transportation tasks (BBC 2011).

Social considerations regarding the rights of local people were not taken into account; they feel they do not benefit enough from the water being abstracted and brought directly to the North, and have suggested a revision of the Project Company's Environmental and Social Management Plan. The legacy of social exclusion was also evident at the time when agri-businesses were using fossil water for irrigation, in order to export crops. The rights of the local Bedouins to benefit from that water were ignored; the rights of the agri-businesses and global consumer were prioritised over the local communities. The question of 'prior use rights' for local populations of arid countries over their non-renewable water resources were raised. 'Prior use, or historical right' is internationally recognized as a tool for negotiations of international treaties and agreements among States, however a 'prior use right' cannot be established at a lower scale: at the individual level. This is why a local Bedouin from the Disi area cannot claim any prior right over a foreign citizen consuming a watermelon irrigated from the Disi. International water law is promoting the principles of 'equitable use and no harm' in the management of shared water, but only among State-entities or sub-regional institutions, not among individuals. Herein lies the problem of how to deal with 'water rights' and 'environmental justice'. There exists a gap between the meaning of justice and equity for individuals and 'equitable use' in international water law.

Another important consideration that must not be ignored is the interaction of virtual water and the Disi groundwater dispute over time (Greco 2013). If we look at the storyline of the project, the agri-business companies can be considered a "virtual water flow" exporting Disi water outside the country. This virtual water flow started when there was no concern about the transboundary nature of the aquifer, but at a later stage of analysis, it is influencing the hydro-politics of this transboundary groundwater basin. As a matter of fact, after the creation of this virtual water flow, Jordan acquired a de-facto right to pump water over Saudi Arabia. While Saudi abstractions started earlier than on the Jordanian side, the virtual water flow has changed the position of Jordan forever, in view of a possible bilateral treaty between the two countries. The allocation of the Disi water will be switched from agriculture to urban supply, thus stopping the virtual water flow. Nevertheless, the Jordanian 'acquired right', created thanks to the virtual water flow, will be a 'de-facto' situation that will play a role in any future development of a bilateral agreement between the two countries. Even if the urban supply should start in 2014 or even later, Jordan will always be in a position to claim that Disi water had been pumped by Jordan since the 1980s. This is a good example of how virtual water can alter and drive power relations in transboundary water issues and, more in general, in hydro-political complexes (Greco 2012).

Social justice, environmental justice, the impact on future generations and the threat of a sudden depletion of the aquifer are all part of this emblematic case of 
groundwater exploitation. As long as there is no bilateral treaty in force, no precise projection of the duration regarding the water provision for Amman, no regulation of environmental and social balance between local, national and international water-consumers, and between current and future generations, the Disi will be "pumped to the bottom", until the very last drop.

\section{Case Study 3: The Sandveld, Cape West Coast, South Africa}

The northern Sandveld, situated approximately $250 \mathrm{~km}$ north of Cape Town, consists of a coastal plain along the west coast of South Africa (Fig. 10.3). It is bordered by the Olifants River catchment in the north and east, the Berg River in the south and the Atlantic Ocean in the west. It is a sandy area comprising granular primary aquifers and deeper fractured rock secondary aquifers, with a high degree of connectivity between the aquifers. The Sandveld is primarily comprised of three parallel seasonal river systems, namely the Jakkalsvlei River, the Langvlei River and the Velorenvlei, as well as a number of smaller systems. The catchments drain westwards through the Sandveld and consist of a combination of rivers, pans and wetland systems. The Ramsar designated Velorenvlei wetland system is the best known of the three systems (DWAF 2008).

The northern Sandveld $\left(4,827 \mathrm{~km}^{2}\right.$ in area) is a rural area with extensive farming, a few towns (Lambert's Bay, Elands Bay, Graafwater, Leipoldtville, Paleisheuwel and Redelinghuis), with fishing and tourism developments along the coastline. Most of the towns, as well as all agricultural developments in the region are supported from groundwater supplies. The main agricultural activity within the study area is the cultivation of potatoes. The water balance for the area (obtained by taking into account groundwater recharge minus discharge and abstraction estimates) ranges from $4 \%$ to $106 \%$ (i.e. significant over-abstraction). This is supported by observed dropping of groundwater levels in this over-abstracted area (DWAF 2006).

Potato farming, primarily is under centre-pivot irrigation systems and is the economic mainstay of the coastal plain. The potato industry employs some 3,250 workers. Between 6,000 and 7,000 ha of potatoes are planted annually in the Sandveld for the production of seed potatoes, potatoes for the fresh market and potatoes for the processing industry (French fries, crisps and frozen products). To limit the carry-over of soil borne diseases a rotation of up to 5 years is specified for the production of seed potatoes. In practice, a farmer wanting to cultivate 20 ha of seed potatoes would need to clear four 20 ha circles ( $80 \mathrm{ha}$ ) and would cultivate one circle per year, moving the centre pivot to the appropriate field each year. Nearly all plantings are irrigated. Farming input costs are high and environmental and other farming conditions often pose great challenges to the farmer in maintaining a viable enterprise (Knight et al. 2007).

Most of the native vegetation, which is being cleared for the cultivation of potatoes, is described as an open semi-succulent scrub of Fynbos form intermediate between Coastal Fynbos and Succulent Karoo (Acocks 1988). The total number of centre pivots in the potato production area of the Sandveld has been calculated as 1,773 (with a combined area of 30,740 ha) using satellite imagery (2003/2004) (Knight et al. 2007). Land clearing has a significant impact on the ecology of the 


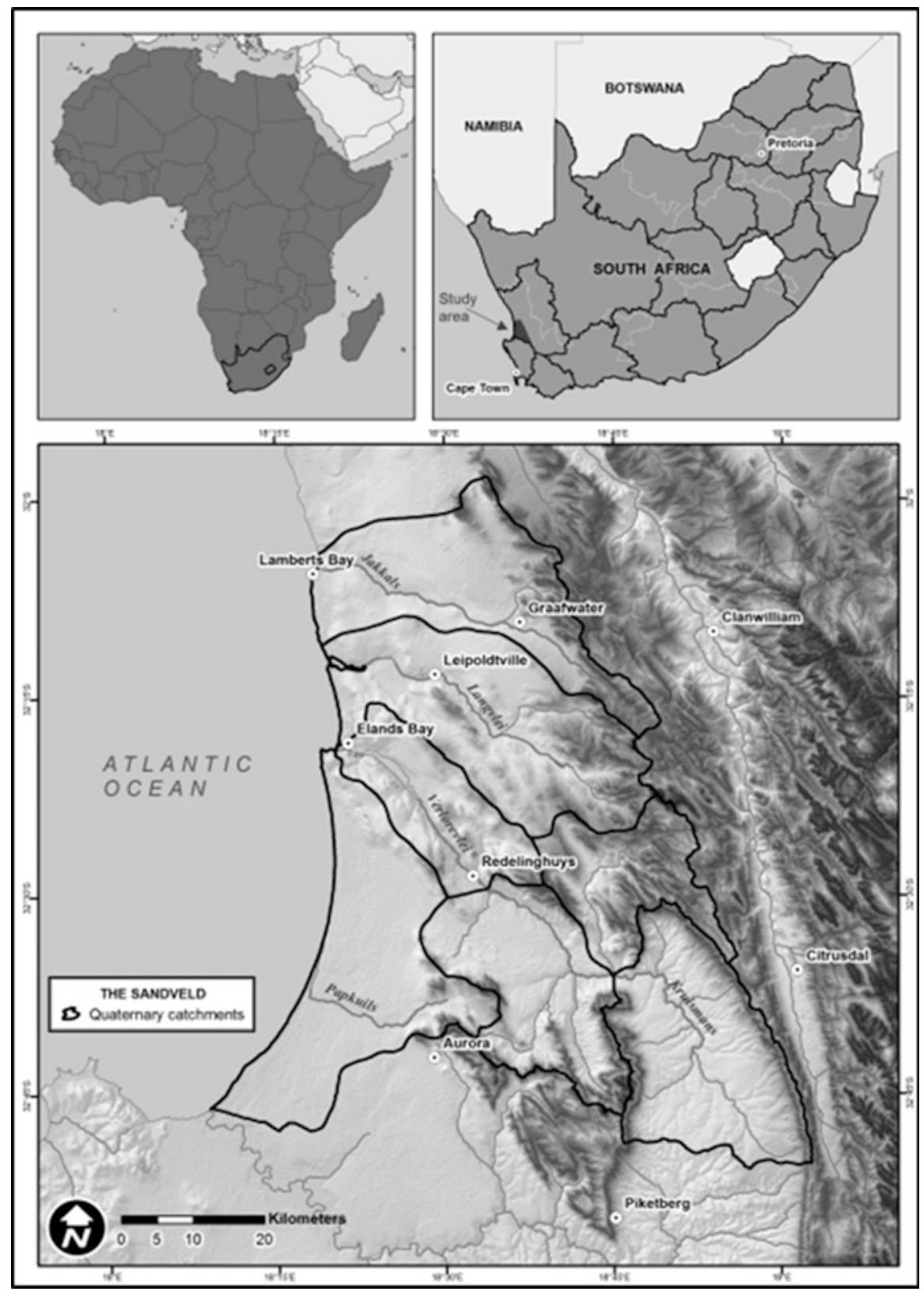

Fig. 10.3 Location of Sandveld, South Africa 
area because once the land is cleared it will never recover to its natural state. Based on broad water balance calculations for the northern Sandveld (which vary from year to year), approximately $64 \mathrm{Mm}^{3} / \mathrm{a}$ is received as groundwater recharge from precipitation; the amount of groundwater required for full ecological functioning is $\sim 29 \mathrm{Mm}^{3} / \mathrm{a}$, the volume of groundwater abstracted for irrigation is $\sim 51 \mathrm{Mm}^{3} / \mathrm{a}$ and the volume of groundwater abstracted for municipal supply equates to $\sim 1 \mathrm{Mm}^{3} / \mathrm{a}$. Thus it is evident that the agricultural abstraction impacts significantly on the ecological functioning of the area. It has been observed that certain wetlands have desiccated, certain spring flows have reduced, groundwater levels have dropped in places with an associated deterioration in groundwater quality and in one area salt water intrusion has occurred. These impacts are particularly noticeable at the lower end of the catchments where production boreholes are too closely spaced (and typically where groundwater is abstracted for multiple purposes e.g. town supply and agricultural needs).

The intense development of good to marginal quality groundwater in coastal aquifers makes the water resources vulnerable to long-term over-abstraction and the intrusion of poor quality groundwater and/or seawater. Proper resource assessment, abstraction plans and monitoring is crucial for sustainable use of groundwater in these coastal areas, where agricultural interests in the catchment must also be served.

There have been many initiatives to address and protect the long term viability of the resource. Some of them include: Environmental Water Reserve studies have been completed and approved; Water User Associations have been established; monitoring is being continued in the area and a Sandveld Integrated Water Resource Management (IWRM) Plan (that will give clear guidance on the way forward for an equitable and sustainable use of the water resources within the area), has been developed. In addition the umbrella organisation of the potato industry, Potatoes South Africa, has invested in the long term monitoring of the impacts of the potato agriculture on the groundwater resources of the Sandveld. The importance of responsible groundwater use has been emphasized to the farmers within the area and there is an increased awareness of the importance of groundwater and its conservation. The northern Sandveld is a complex area where social, economic and environmental water needs are all inter-dependent and a careful balance is required to meet all the demands on the water resources of the area to ensure its long term viability.

\subsection{Synthesis}

The case studies described above illustrate how the natural environment in general and the groundwater resource in particular underpins a broad range of social, political and economic activities, and why it is important to act cautiously when exploiting a resource with many unknowns, most especially unknown extraction limits before negative ecological impacts ensue. In both the Disi Aquifer and the Sandveld case studies it is apparent that the long term prospects of the social and 
economic activities will be undermined if there is no due consideration for the environmental limits of the underpinning groundwater resource. Not only are there direct injustices caused by environmental degradation and reduced groundwater for subsistence agriculture, but the injustices can also spill out of the environmental and social domain into the economic domain and impact on the long term sustainability of large agro- producers and exporters. In other words 'the ability to meet the needs of the present without compromising the ability of future generations to meet their own needs' (WCED 1987) is threatened.

The social dilemma posed by water allocation decisions centres on who or what use should get priority and in what circumstances. In the Daly River case study the dilemma is whether water should be distributed for environment and cultural uses or for irrigated agriculture. In the Disi Aquifer case study the allocation dilemma has arisen because of a change in allocation rules; initially the rationale for allocation was primarily economic driven but now increasing social demands (urban water use) is shifting the priority of use and is causing problems. The distributional dilemma can also be framed as one of long term vs short term, illustrating how important the temporal aspect is in justice considerations; for the Disi and the Sandveld it is a case of long term environmental sustainability of the resource vs the shorter term economic activity of irrigated agriculture.

The process of inclusion and exclusion of certain stakeholders or interests has been examined in the justice literature and falls within the discourse of procedural justice and public participation. Susan Opotow explores it in the context of environmental conflicts and has termed it the scope of justice (Opotow and Weiss 2000). The scope of justice, also known as the scope of moral exclusion, has been defined as the psychological boundary for fairness (Opotow and Weiss 2000) or the boundary within which justice is perceived to be relevant (Hafer and Olson 2003). Principles of justice govern our conduct towards those within our scope of justice, while moral exclusion rationalises the denial of those outside our scope of justice (Opotow and Weiss 2000) and thus enables and rationalises the application of justice principles (such as those described in Table 10.1) in an inconsistent or even in an unjust manner. In the Disi case study groundwater resources are being mined - this is old water i.e. a non-renewable resource - the significance of this fact and future environmental interests are not taken into account or included within the scope of justice. In addition the local communities' interests are not taken into account - i.e. not included in the scope of justice - therefore there are problems arising because procedural justice rules haven't been adhered to. In the Sandveld case study all interests have been taken into account - social inclusion and procedural justice issues are considered; the justice question here centres on whether long term needs vs short term gains will take priority.

Each case study has a number of proponents that will construct their argument for why they believe they should receive priority of water use from the families of justice outlined in Table 10.1 -the ultimate question is which one makes the case that will result in just and equitable outcomes and more importantly where the burdens of the unjust outcomes will fall if social and environmental justice is not the overarching goal. 


\subsection{Joining the Dots: Justice, Governance and Sustainability}

Water governance can be defined as a system for managing water according to objectives that reflect the goals of society. This system includes various organisations such as government departments, non-government organisations and civil society groups, and a range of institutions such as principles, policies, regulations, legislations and social norms that operate at a variety of levels (Ashton et al. 2005; North 1990). As environmental discourses and water management paradigms have evolved, so too have the structure and mandate of water governance systems.

The link between sustainability and justice has been explored at the conceptual level and has been termed Just Sustainability by Agyeman (2005a, b). Just Sustainability is best described by briefly recapping the origins of both environmental justice and sustainability. Environmental justice rose to prominence shortly after the civil rights movement in the United States of America and focused on the locating of toxic waste sites in close proximity to minority residential communities. Rallying around this and other forms of environmental racism led to the emergence of grassroots activism that protested against development and policy that did not embrace the principle that all people and communities are entitled to equal protection under environmental and public health laws and regulations (Towers 2000). The definition and scope of environmental justice has evolved since this initial movement around local environmental hazards and is now widely acknowledged and understood by many environmental justice organisations to include broader social justice considerations (Agyeman and Warner 2002). It does however run the risk of focussing too narrowly and solely on the community level in finding solutions to injustices.

The concept of sustainability emerged from the opposite end of the spectrum - a global rather than a grassroots phenomenon. Although its beginnings pre-date the 1972 United Nations Conference on the Human Environment in Stockholm, sustainable development was popularised through this event; and then progressively mainstreamed into our collective consciousness and policies through the 1983 World Commission on Environment and Development and the subsequent publication of Our Common Future in 1987; the 1992 World Summit in Rio de Janeiro and the publication of Agenda 21; the 2002 World Summit for Sustainable Development in Johannesburg and the publication of the Plan of Implementation, and lastly the 2009 World Conference on Education for Sustainable Development held in Bonn and the publication of the Bonn Declaration. Sustainable development emerged as a response to the recognition that many of the environmental problems that we currently face are now manifest at a global level and that individual NationStates or a piecemeal response to these problems would be unsuccessful in addressing them. Sustainability has now become a "higher order social goal" (Dovers 2005, p. 8). It aims to address the bigger picture but it can potentially lose sight of the social justice dimension of meeting the needs of current generations. 
One of the major tensions between the two concepts is scale related. Environmental justice claims are often initiated at the local - grassroots - community level, while calls for sustainability are usually more strategic in nature and are often initiated at the regional, national or international level. The proponents of sustainable development have recognised the conflict between the need for an overarching vision and the practical implementation of action plans at a more local level through the Local Agenda 21 programme and the Johannesburg Plan of Implementation; but there is still continuing and growing poverty and environmental degradation. This tension presents an opportunity for synergy between the two concepts - the strengths of one make up for the weaknesses in the other. It is clear that there exists an imperative to include justice issues into the higher social goal of sustainability, but it cannot be achieved if there is a perpetuation of social exclusion, be it racism or classism, or the exclusion of any other social, economic or environmental voice. Agyeman suggests this revised rationale for sustainability: "The need to ensure a better quality of life for all, now and into the future, in a just and equitable manner, whilst living within the limits of supporting ecosystems" (2005b, p. 17).

\subsection{Conclusion}

Social - Environmental justice is a useful lens in the arsenal of researchers, policy makers and natural resource managers that can be used to highlight the importance of a systems approach when dealing with common pool resources such as groundwater - it can highlight the inter-connectedness of systems and the potential social, economic and environmental consequences of disregarding this inter-dependency.

Three important and necessary questions that a justice perspective offers that are likely to improve groundwater governance if answered include:

1. What underlying 'rules' have been used to make a water allocation decision. Have both distributional justice and procedural justice rules been taken into account?

2. Which justice theory, model or principle has been used as the rationale for how the water resource is shared? Does the underlying rationale draw from the economic, social, rights-based or environmental family of justice theories (or a combination of families) and how does this potentially influence the outcome?

3. Who or what has been included and excluded from the scope of justice or scope of the decision-making process and for what reasons?

It is important to be explicit about answering these challenging questions because if the social, political, economic and environmental aspects of groundwater management are not taken into account, this could and has led to reduced groundwater levels to such an extent that sites of cultural significance are lost, local and small scale subsistence farmers have no access to water, tensions between countries might arise over shared water resources, native biodiversity is lost and the long term investment in commercial agriculture is threatened. 
Open Access This chapter is distributed under the terms of the Creative Commons AttributionNoncommercial 2.5 License (http://creativecommons.org/licenses/by-nc/2.5/) which permits any noncommercial use, distribution, and reproduction in any medium, provided the original author(s) and source are credited.

The images or other third party material in this chapter are included in the work's Creative Commons license, unless indicated otherwise in the credit line; if such material is not included in the work's Creative Commons license and the respective action is not permitted by statutory regulation, users will need to obtain permission from the license holder to duplicate, adapt or reproduce the material.

\section{References}

Acocks JPH (1988) Veld types of South Africa, 3rd edn. Memoirs of the botanical survey South Africa no 28. Government printer, Pretoria

Adams JS (1963) Toward an understanding of inequity. J Abnorm Soc Psychol 67:422-436

Agyeman J (2005a) Sustainable communities and the challenge of environmental justice. New York University Press, New York

Agyeman J (2005b) Where justice and sustainability meet. Environment 47:10-26

Agyeman J, Warner K (2002) Putting 'just sustainability' into place: from paradigm to practice. Policy Manag Rev 2:8-40

Allan JA (2005) Water in the environment/socio-economic development discourse: sustainability, changing management paradigms and policy responses in a global system. Gov Oppos 40 (2):181-199, Blackwell Publishing, Oxford

Ashton PJ, Patrick MJ, Mackay HM, Weaver A (2005) Integrating biodiversity concepts with good governance to support water resources management in South Africa. WaterSA 31:449-456

BBC (2011) BBC monitoring Middle East. BBC, London. http://search.proquest.com/docview/ 822342242. Accessed July 2013

BGR (2013) Groundwater basins and transboundary aspects in Jordan. www.bgr.bund.de. Accessed June 2013

Blanch S (2004) Submission-in-progress to the water allocation plan for the Daly region. World Wildlife Fund for Nature Australia, Darwin

Blanch S, Rea N, Scott G (2005) Aquatic conservation values of the Daly River catchment Northern Territory, Australia. A report prepared by World Wildlife Fund. Charles Darwin University, and the Environment Centre NT, WWF Sydney, Sydney

Brockner J, Wiesenfeld BM (1996) An integrative framework for explaining reactions to decisions: interactive effects of outcomes and procedures. Psychol Bull 120:189-208

Colquitt JA, Conlon DE, Wesson MJ, Potter COLH, Yee Ng K (2001) Justice at the millennium: a meta-analytic review of 25 years of organisational justice research. J Appl Psychol 86:425-445

Deutsch M (1975) Equity, equality, and need: what determines which value will be used as the basis of distributive justice? J Soc Issues 31:137-149

DNREA (2006) Conjunctive water management and Northern Territory water policy. Department of Natural Resources, Environment and the Arts, Northern Territory. www.connectedwater. gov.au/water_policy/nt_persepective.html. Accessed Dec 2006

Dovers S (2005) Environment and sustainability policy: creation, implementation, evaluation. The Federation Press, Sydney

DWAF (2006) Groundwater reserve determination for the Sandveld, Olifants-Doorn Water Management Area, Compilation of a high confidence ecological reserve for the groundwater, wetland and salt pan components. Consulting report for the Department of Water Affairs and Forestry. Compiled by Conrad J, and Munch Z, Pretoria

DWAF (2008) Integrated water resources management plan for the Sandveld, Olifants Doorn Water Management Area, Western Cape, Background information to management plan. 
Consulting report for the Department of Water Affairs and Forestry. Compiled by Belcher A, Conrad J, and Grobler D, Pretoria

Ferragina E, Greco F (2008) The Disi Project: an internal - external analysis. Water Int 33:451-463

Foster S, Loucks DP (2006) Non renewable groundwater resources, IHP VI - series on groundwater no 10. UNESCO, Paris

Giordano MA (2009) Global groundwater? Issues and solutions. Annu Rev Environ Resour $34: 153-178$

Goldenberg S (2014) Why global water shortages pose threat of terror and war. The Guardian. www.theguardian.com/environment/2014. Accessed 11 Mar 2014

Greco F (2012) Adding an historical perspective to virtual water flows: hydrometabolism and the history of virtual water rivers. AAG 2013. Available at http://bit.ly/ZUcDjo

Greco F (2013) Hegemony and counter-hegemony in virtual water trade: justice for indigenous people? In: Proceeding of the 6th Hydro Hegemony workshop on transboundary water justice, London

Gross C (2011) Why justice is important. In: Connell D, Grafton RQ (eds) Basin futures: water reform in the Murray-Darling Basin. ANU E Press, Canberra

Hafer CL, Olson JM (2003) An analysis of the empirical research on the scope of justice. Pers Soc Psychol Rev 7:311-323

Jackson S (2004) Preliminary report on aboriginal perspectives on land-use and water management in the Daly River region, Northern Territory. Report to Northern Land Council, CSIRO Sustainable Ecosystems, Darwin

Jackson S (2005) Indigenous values and water resource management: a case study from the Northern Territory. Aust J Environ Manag 12(3):136-146

Jackson S (2006) Compartmentalising culture: the articulation and consideration of indigenous values in water resource management. Aust Geogr 37:19-31

Jackson S, Storrs M, Morrison J (2005) Recognition of aboriginal rights, interests and values in river research and management: perspectives from northern Australia. Ecol Manag Restor 6:105-110

Knight F, Conrad J, Helme N (2007) Biodiversity: best practice guidelines for potato production in the Sandveld. Report compiled for Potatoes South Africa and CapeNature and funded by Conservation International, Potatoes SA and Woolworths, Pretoria

Leventhal GS (1976) What should be done with equity theory? New approaches to the study of fairness in social relationships. National Science Foundation, Washington, DC

National Water Commission (2004) National water initiative. Intergovernmental agreement on a National Water Initiative Council of Australian Governments (COAG)

North DC (1990) Institutions, institutional change and economic performance. Cambridge University Press, New York

Opotow S, Weiss L (2000) Denial and the process of moral exclusion in environmental conflict. J Soc Issues 56:475-490

Schroeder DA, Steel JE, Woodell AL, Bembenek AF (2003) Justice within social dilemmas. Pers Soc Psychol Rev 7:374-387

Shapland G (1997) Rivers of discord: international water disputes in the Middle East. Hurst, London

Skitka LJ, Crosby FJ (2003) Trends in the social psychological study of justice. Pers Soc Psychol Rev 7:282-285

Thibaut J, Walker L (1975) Procedural justice: a psychological analysis. Wiley, New York

Towers G (2000) Applying the political geography of scale: grassroots strategies and environmental justice. Prof Geogr 52:23-36

UN (2010) Declaration of water and sanitation as a human right. General Assembly GA/SHC/ 3987. Human Rights Council. www.un.org/en. Accessed Oct 2011

UNESCO (2012) Groundwater and global change: trends, opportunities and challenges. United Nations World Water Assessment Programme. UNESCO, Paris 
USGS (2013) Water data banks project, multilateral working group on water resources, middle east peace process. Overview of Middle East water resources. http://exact-me.org/overview/ p12.htm. Accessed June 2013

Wada Y, Heinrich L (2013) Assessment of transboundary aquifers of the world - vulnerability arising from human water use. Environ Res Lett 8:13pp

WCED (1987) Our common future. World Commission on Environment and Development. Oxford University Press, Oxford. Available online: http://www.un-documents.net/wced-ocf. htm

Wenz PS (1988) Environmental justice. State University of New York Press, New York 